\title{
Avoidance and Overuse of Indonesian Language among Balinese Children
}

\author{
Wayan Pageyasa* \\ FKIP, Universitas Sembilanbelas November Kolaka, Indonesia \\ Corresponding author: Wayan Pageyasa, E-mail: wayanpageyasa@gmail.com
}

\section{ARTICLE INFO}

Article history

Received: May 20, 2017

Accepted: September 04, 2017

Published: October 31, 2017

Volume: 5 Issue: 4

Conflicts of interest: None

Funding: None

\begin{abstract}
The use of Indonesian language by children who speak the Balinese language, especially for children who live in rural areas is quite difficult. This is because their Balinese language is much different from Indonesian language. If they speak Indonesian language, they have to fall back to the language first. That is, language transfer process will take place from Balinese language to Indonesian language. This research aims to describe two phenomena of the language transfer process, namely avoidance and overuse (excessive use). Qualitative data were obtained from one Balinese child, namely Gede. Gede's daily conversations were recorded to be analyzed. The researcher also used field notes. The results show that there is indeed avoidance and overuse in the use of Indonesian language by Gede. The teachers must be aware of the student's avoidance and overuse of Indonesian language, then the teacher can choose a contextual teaching method that best fits their students' need in order to enable them to cope with the avoidance and overuse in learning the second language. In conclusion, the Balinese child's avoidance and overuse, displayed in his use of Indonesian Language, is a concequence of his prior knowledge of his first language (L1) as well as his cultural awareness. Teachers should facilitate their students' second language (L2) learning by being aware of their L1 prior knowledge and culture.
\end{abstract}

Key words: Avoidance, Overuse, Indonesian Language, Balinese Children, Balinese Mother Tongue

\section{INTRODUCTION}

Language transfer is a general term for describing the influence of learners' first language (L1) prior knowledge on their second language (L2) learning (Brown, 1980, cited in Rahayu, 2012). It is an automatic process which unconsciously happens in employing learning experience and knowledge to generate a new response (Brahim, 1995, as cited in Rahayu, 2012). It is divided into two types; namely, positive transfer and negative transfer. Positive transfer associates with the production of new appearance or new behavior that conforms to the prevailing norms. This new behavior is generally similar to the old behavior. Therefore, positive transfer occurs when there is a similarity between L1 and L2. In contrast, negative transfer associates with the behavior that is against the old behavior resulting in errors. Unlike positive transfer, the new behavior in negative transfer is generally different from the old behavior. In L2 learning, negative transfer occurs when the structure of two languages is different.

Brahim, 1995 (as cited in Rahayu 2012) explains that the notion of first language acquisition interference towards the second or target language was first found in the process of learning a foreign language. There is research evidence indicating that students' L1 significantly influences the process of $L 2$ acquisition.
L2 learners often use their L1 knowledge and culture actively in learning, speaking or writing or passively in learning, listening and reading in L2. This tendency emerges since learners are not familiar with the L2 forms. As a result, their language acquisition is more influenced by their L1 that they have mastered (Ellis, 1986 cited in Susanto, 2012)

James (1980, cited in Rahayu, 2012) states that the interference theory predicts if the learners produce the second or target language, but they do not fully master it, they tend to make mistakes and errors. For those who do not comprehend the theory yet, they make mistakes both in oral and written form. This assumption is based on the behaviorist theory that is the study of stimulus and response phenomena in which learners will give responses over the stimulus within a context. If learners concurrently learn new responses and at the same time get the stimulus, the old stimulus will disappear and a mixture between the old stimulus and new responses or conversely the old responses with the new stimulus will reveal. Dulay (1970, as cited in Chaer, 2009) explains that this happens mainly because L2 learners are un/consciously transferring the element of L1 into L2 when they learn second/foreign language.

However, the mixture between the old-new stimulus and the response will disappear if learners master the new language. These two types of negative transfer occur in second language learning process are avoidance and overuse. Both 
of these phenomena are considered as mistakes due to the performance factor. Their examination will greatly assist second language teachers to understand the difficulties and constraints of learners in learning a language which is affected by their cultural background. An in-depth comprehension of these phenomena can help second language teachers easily identify their learners' difficulties and provide them with solution.

In this study, the researcher took a Balinese child as a sample. The Balinese children, who speak Balinese language as their mother tongue, tend to have difficulty in speaking Indonesian. The two phenomena of negative transfer mentioned earlier seem to be the main obstacles in learning Indonesian language for Balinese children. Balinese children's mother tongue differs from Indonesian language as the latter has many different words with varying final phonemes. Awareness of this fact specifically with the related phonemes will definitely help learners' acquisition process of Indonesian Language. In contrast, failing to understand this case will mislead them in mastering Indonesian which is different from their mother tongue. Here are some examples:

kend in Indonesian is kena [touching]

mat $\partial$ in Indonesian is mata [eye]

but $\partial$ in Indonesian is buta [blind]

bis $\partial$ in Indonesiann is bisa [can]

ragd in Indonesian is raga [body]

The distinction of L2 Indonesian learners from $\mathrm{Ba}$ linese language as their mother tongue will analogously form "mini theory" in their thought. Balinese can be easily transferred into Indonesian language by only changing the last phoneme. For instance, the word ' $\operatorname{rag} \partial$ ' in Indonesian

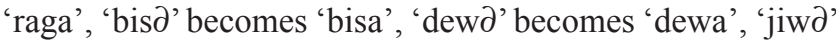

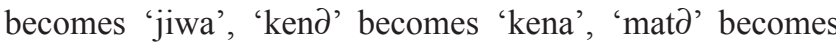

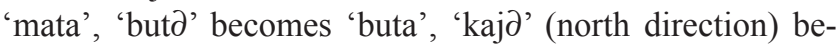
comes 'kaja', 'manggd' becomes 'manggo', etc. This mostly occurs in Balinese children who live in rural areas and learn Indonesian as their second language.

The acquisition process, therefore, is inseparable from the language transfer phenomenon. In this, linguists assume that the complex issue faced by language learners is mainly affected by their first language. Then the distinction between two different languages being learned becomes the nuisance in their language learning process.

Similarly, Balinese children encounter the same problem, especially for those who live in remote areas. The acquisition of Indonesian language becomes quite difficult compared with those who live in cities. This is because in their daily interaction, they use Balinese language as the medium which is partially different from Indonesian language that they need to master. As a result, a language transfer occurs from Balinese to Indonesian.

In the middle of March 2015, the researcher conducted a preliminary study. He found two language transfer phenomena that occurred in the acquisition of Indonesian language, namely avoidance and overuse. Avoidance occurs when learners avoid using specific language items or structures in the second language. This is the result of their mother tongue interference that has taken root in them. It can be in the form of language structure or in the form of culture that is carried by Balinese speakers. In Balinese culture, there is a form of politeness in the language namely sor singgih. In addition, it is realized in the form of evasion. This will attack the process of Indonesian language acquisition. Overuse in this context, means over generalization that can lead to errors in learning of Indonesian language. Making such errors hinders the process of mastering a second language.

Both mentioned phenomena can cause problems for learners and need to be investigated and explained. It is hoped that the results of this research provides implications for second language learners. Moreover, the findings will facilitate students to master second language by designing a classroom practice. In this, processes such as designing study materials, choosing teaching strategies and methods will be facilitated. In addition, the results of this study can be a reference for other researchers who are interested in conducting further studies in this area. The results are expected to contribute theoretically to the language acquisition process and can be useful in practice as a reference for designing lesson plans to language learners.

\section{Objective}

The main objective of the current research is to describe the negative transfer phenomenon in Balinese children's acquisition of Indonesian language.

\section{Research Question}

To meet the above-mentioned objective, the current research seeks to answer the following questions:

- How are avoidance and overuse displayed by a Balinese child in his use of Indonesian Language?

\section{LITERATURE REVIEW}

The term "acquisition" refers to a process of mastering a language encountered by a child naturally when he learns his mother tongue (native language). Language acquisition is usually distinguished from language learning. Language learning deals with the processes that occur when a child formally learns a second language after he/she acquires his/ her first language. Thus, language acquisition is concerned with first language, while language learning is often related to second language.

Second Language Acquisition (SLA) is not a predictable phenomenon. The ability to acquire a second language is determined by two main factors. They are internal factors (from within individuals, such as age, talent, cognition, motivation, and personality) and external factors (from outside the individual, such as the language situation and learning strategies).

Based on this fact, we can distinguish several types of second language acquisition (SLA). The fundamental difference is that, they are guided by nature and by nurture. According to Krashen and Teller (1983), in general, developing skills of first language is called acquisition while develop- 
ing second language (SLA) is called learning. Acquisition is spontaneous, whereas learning is structured.

Schutz (1998) stated the 5 points of the natural approach hypothesis by Krashen, namely, acquisition learning hypothesis, input hypothesis, natural order hypothesis, monitor hypothesis, and the affective filter hypothesis:

1. According to acquisition learning hypothesis, an L2 adult learner can keep in mind the internalize rules of L2 in implicit (unconscious acquisition) and explicit ways (conscious or deliberate learning).

2. In input hypothesis, one is expected to be able to understand the elements and structure of the language called $\mathrm{i}+1$ ( $\mathrm{I}$ is the level of current language ability and $\mathrm{i}+1$ represents the next level). In this case, it is necessary for adults to teach the language by modifying the language in various ways. Thus, the input given to the child includes the next linguistic level corresponding to the formula $i+1$.

3. In natural order hypothesis, the structure of second language acquisition runs in a predictable order.

4. The monitor hypothesis describes that acquisition and learning influence each other. The function of monitoring process is the result of the learner's performance. Krashen holds that the acquisition system is the utterance initiator, while the learning system performs the role of the 'monitor' or the 'editor'. The 'monitor' performs planning, editing, and correcting functions when specific conditions are met; that is, second language learners have sufficient time at their disposal, they focus on form or think about correctness, and they are aware of the rule. It is supposed that learners' conscious role limit their second language performance. Krashen proposed that the monitor's role should be minor. It should be used only to correct deviations from a normal speech and to give an appropriate speech. Later on, he suggests that there is an individual variation among language learners toward the utilization of monitor. The second learner focuses his attention on the form and truth of speech grammatically as well as to be aware of it; he must know the rules of second language grammar. Monitor users are divided into three categories. The first one is over-users who have really high demands so they are too cautious and very careful in producing language. The second one is under-users who rely only on what they know without thinking about the actual rules, so they do not really have a high accuracy of language production. The third one is optimal-users who use their learning outcomes as a complement to their acquisition, so that they resemble the native speakers. In addition, lack of self-confidence is usually associated with overuse of the "monitor".

5. In the affective filter hypothesis, a second language learner with a certain motivation is more successful than those who have no motivation. The success of the second language learner is determined by the low level of anxiety which could have an impact on the low affective filter. In other words, learners do not have feelings of tension and anxiety so that they are more open to language input that will come into mind. Eventually, learners receive encouragement to obtain more input, and become more receptive to input.

In addition, some researches on second language acquisition showed different patterns (Rahayu, 2012; Yunita, 2012). In her study, Yunita (2012) investigated two samples and found that the two respondents acquired the target language (Indonesian) differently. The first respondent frequently switched her language which was Javanese to Indonesian language. As a result, she spoke Indonesian with a Javanese accent. At the same time, the second respondent, who rarely spoke Indonesian since her mother tongue was Javanese, intentionally switch languages between Indonesian and Javanese. The aim of this code switching was to elaborate the meaning and to drive the listener to follow the speaker. In another study that shows the different pattern of learning language process, Rahayu (2012) found that Indonesian language and English language have both differences and similarities in their structure. The similarity in the structure of the two languages can lead to a positive transfer and in this case the word order of sentence of English and Indonesia. On the other hand, interference or a negative transfer could be found where there is difference between the two languages with regard to certain aspects such as the phonology.

According to the behaviorists theory, learning L2 is an effort to control the habit of L2 (new language habits) by means a way to memorize dialogue, mimic, the utterance of others, or to train the use of language patterns. In acquiring new habits, learners transfer the old habits (L1) into new habits (L2) (Tolla, 1990, p. 7). This is similar to what Bright and McGregor (1970, as cited in Ellis, 1986) state; that is, the old habits will be turned into new habits of learning. Therefore, if second language acquisition is taught, the grammatical tools that have been processed in human brain such as the first language can easily interfere with the second language acquisition process. To conclude, the notion of interference occupies the first place in second language acquisition. Interference is caused by propagation barriers (proactive inhibition) which are associated with the prior way of learning that prevents or inhibits learning new habits.

Moreover, in the view of behaviorism theory, errors are not expected to occur. Errors are evidence of the absence of learning that is the failure to eliminate the propagation of obstacles. Some language teaching theorists claim that there is a danger of mistakes that become customary in the language of the learners if errors are not avoided. Brooks (1960, as cited in Benešová (2013) wrote, like sin, error is to be avoided and its influence overcome, but its presence is to be expected. However, since mistakes are caused by the negative transfer of the first language habits, it is difficult to see how an error becomes a habit and how we let it become a habit. Errors according to behaviorism are not caused by mislearning or not learning. In both cases, there is an agreement that mistakes should be avoided. Then, effort is made to predict when errors will occur.

\section{METHODS}

The current study is a contrastive analysis research that applied a qualitative design. Error analysis emerged as a re- 
form of contrastive analysis which is assessed just to show a significant role in identifying difficulties associated with the phonemic level and a little bit on the grammatical level. It should be mentioned that the application of error analysis focuses more on the evaluation phase of the three stages of learning. They are planning, implementing, and evaluating. The purpose of this research is to find out language learning difficulties faced by Balinese children that lead them to commit avoidance and overuse errors. The findings are expected to help in planning the foreign language learning for Balinese children. Thus, the researcher preferred to use contrastive analysis to this end.

This is in line with Zaharan's (nd, as cited in Naska, 2017 ) idea) in that contrastive analysis, with its role as predictor, is a part of the planning stage of learning, while error analysis implication associated with the evaluation stage. In addition, this study is conducted to find out difficulties faced by Balinese Children in learning Indonesian as the second language.

Furthermore, contrastive analysis emerged due to the emergence of efforts to enlarge the success of teaching and learning a foreign language or a second language (L2). In this, contrastive analysis can be used to predict students' errors to learn L2. The differences between L1 and L2 manifest some difficulties to students in learning L2. On the other hand, the similarity between L1 and L2 makes it easier for students to learn L2, so that teachers can arrange teaching material according to the level of difficulties faced by students. The contrastive analysis is coined by Robert Lado (1964, as cited in Ellis, 1986) in his book entitled Linguistics across Cultures. He explained that we can predict and describe the patterns that will cause difficulty in learning, and those that will not cause difficulty, by systematically comparing the student's native and the target languages and cultures. Later on, it was introduced and applied as a practical-oriented linguistic approach that seeks to explain the differences and similarities between learners' first language and the target language (Lightbown \& Spada, 2013).

The source of the data was taken from a Balinese child, Gede. Gede is a child with a Balinese cultural background. He lives in Watubangga, Southeaset Sulawesi, Indonesia. It is a rural area where a community of Bali transmigrants resettled in Southeast Sulawesi, Indonesia. He speaks Balinese as his mother tongue. Until his second grade at school, he used Balinese because his environment (school, home, streets) is surrounded by Balinese. When he was 10 years old (grade 3), he moved to a primary school that has students from other tribes. In his new school, the medium of instruction was fully Indonesian language. The study period was six months, starting May $3^{\text {rd }}, 2015$ and ending on November $4^{\text {th }}, 2015$. The data were obtained by audio-recording Gede's speeches and taking field-notes when he was communicating with others. To maintain the authenticity of the data and to avoid the Hawthorne effect, Gede's speeche was recorded secretly as it naturally occurred without any training. Therefore, the research instruments were a recording device and field-notes.
The collected data were analyzed according to the following three phases:

a. Data reduction phase: data identification, classification, and clarification;

b. Data presentation; and

c. Data verification/drawing conclusions

In addition, the researcher conducted two data analysis procedures. First, a comparison has been made between the structure of Balinese as the respondent's first language and his second language. By doing so, the difference between the mother tongue and the second language structure could be identified. Then, based on the structural differences between the two languages, the researcher can predict the learning difficulties and the language errors that might be experienced and produced by the second language learner.

\section{RESULTS}

\section{Avoidance}

Avoidance occurs when there is evidence that native speakers avoid the use of certain vocabularies in 'conscious' state. In other words, the avoidance is reasonable to talk about if the student knows what he avoids. The avoidance occurs when L2 learners know what to say and how to say it but do not want to say it because it can undermine the students' own behavioral norm. This can be noticed in the following conversations.

In sentence (1), the speaker used the word 'diplebon' and avoided the use of the word 'dibakar'. The speaker already knew that the word 'diplebon' in Indonesian is the same as 'dibakar'. However, in the context of Balinese culture, the word 'plebon' is not the same as 'dibakar', as well as the addressee is a respected grandmother. Here, the speaker choose to use the word 'diplebon' which is more polite than the word 'dibakar'. Thus it does not undermine the norm of his own behavior. Similarly, in sentence (2), the use of word 'Gusti Aji' is the avoidance of the word 'ayah'; in sentence (3) the word 'meriki' is an avoidance of the word 'ke sini'. In sentence (4), the word 'melinggih' is the avoidance of the word 'duduk'; in sentence (5) the word 'tinggih' is avoidance of the word 'iya'; in the sentence (6), the word 'tiang' is the avoidance of the word 'saya'; in sentence (7) the word 'sugrd'is the avoidance of the word 'permisi'; in sentence (8) the word 'napi' is the avoidance of the word 'apa'; in sentence (9) the word 'ten' is an avoidance of the word ' $t i$ dak'; in the sentence (10) the word 'benjang' is an avoidance of the word 'besok'; and in sentence (11) the word 'matur suksma' is the avoidance of the word 'terima kasih'.

All forms of avoidance from sentence (2) to (11) occurred because of the speech counterpart who had a higher social status, a Gusti, Guru, and Bendesa. Gusti in ancient times was a title for nobles, and now it is no longer valid. In Balinese society, respecting for those who hold the title Gusti is still there even in a small degree. Master in Balinese society is highly respected and even known as chess masters (four masters who must be respected). Bendesa is a traditional leader who is of course highly respected. Bendesa is the elderly. The words used as a form 


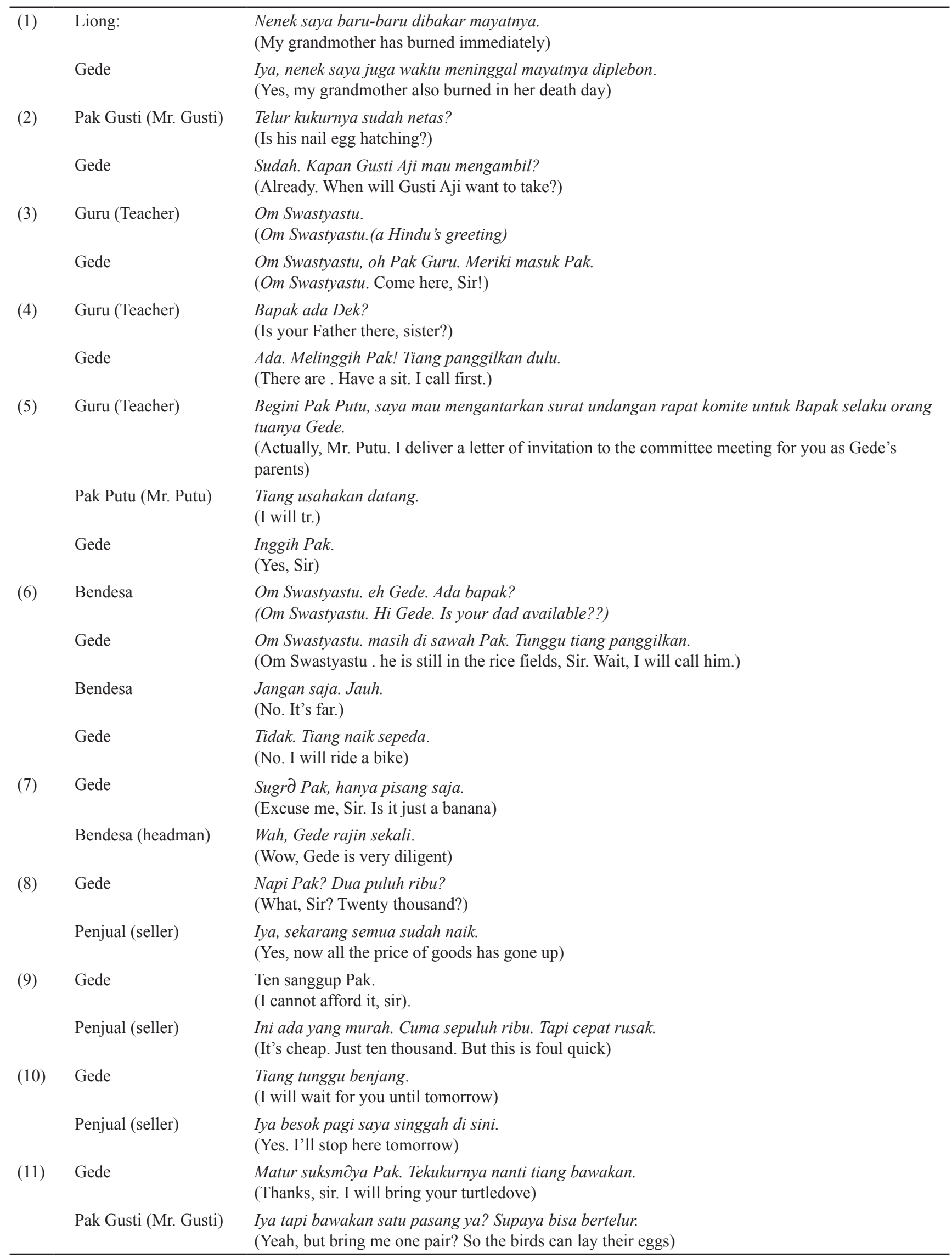

of avoidance above are in the 'subtle' degree which is as a manifestation of respect for the addressee. To be noted, this type of evasion is actually not very influential in the process of language learning because it is done with sufficient knowledge about "politeness" that must be applied while speaking. 
Another form of avoidance occurs when learners know the target language but have difficulty using it in particular situations such as in the context of a free conversation as shown in the following sentences.

In sentences (12), we can notice the use of the word 'maturan' as the avoidance of the word 'sembahyang'. In fact, the learner knows that the Indonesian of 'maturan' is 'sembahyang'. However, he failed to say it. The difficulty to use the word 'sembahyang' emerged because he needed to say the word as fast and soon as possible. Perhaps, if he is asked again "what is 'maturan'?", he would answer 'maturan' is 'sembahyang'. Likewise in sentence (13), the use of the word 'banten' as the avoidance of the word 'sesajen'; in sentence (14) the word 'mancing' is an avoidance of the word 'memancing'; in sentence (15) the word 'ngangon' is an avoidance of the word 'mengembala'; in sentence (16) the word 'nyukutin' is the avoidance of cleaning the grass or weeding the rice; in sentence (17) the word 'pundukan' is an avoidance of the word 'pematang'; in sentence (18) the word 'tajen' is an avoidance of the word 'sabung ayam'; and in sentence (19) the word 'kocok' is evasion from the word 'dadu'.
Also, avoidance can occur if the learners know or anticipate the problems faced or the difference of ideas possessed by the second language. This case is not much found. Let us examine the following sentences. Where are the sentences?

In sentence (20), It can be seen the use of the word 'wareg' as a form of avoidance from the word 'kenyang'(full). Apparently, the speaker deliberately avoids the use of the word 'kenyang'(full) because in Balinese, the word 'kenyang' (full) means somewhat vulgar, namely 'ereksi'(erection); and therefore, the student hesitated to use it. In sentence (21), the use of the word 'ngdrok' (snoring) is the avoidance of the word 'ngorok' (snoring) which in Balinese means 'menyembelih' (slaughter). The learner consciously avoids using it because in Balinese it means terrible. In sentences (22), the use of the word 'kayu manis' (cinnamons) is the avoidance of the word 'katuk' which in Balinese means 'setubuh', it is a vulgar word also; in sentence (23), the use of the word 'bendesa' is the avoidance of the word 'ketua adat'(customary chairman), because in Balinese context, 'bendesa' is not merely the custumary leader but also a religious figure or a religious scholar, in contrast to other indigenous tribal leaders who only deal with customs. Thus, the speaker con-

\begin{tabular}{|c|c|c|}
\hline \multirow[t]{2}{*}{ (12) } & Gede: & $\begin{array}{l}\text { Tok, saya tidak ikut, besok saya mau maturan ke Pura. } \\
\text { (Tok, I do not come, tomorrow I want to pray to the temple.) }\end{array}$ \\
\hline & Anto: & $\begin{array}{l}\text { Ah tidak cukup kalau kamu tidak ikut. } \\
\text { (Ah, that's not fun if you do not come) }\end{array}$ \\
\hline \multirow[t]{2}{*}{ (13) } & Siti: & $\begin{array}{l}\text { Kok beli pisang banyak De? } \\
\text { (How come you buy a lot of bananas, boy?) }\end{array}$ \\
\hline & Gede: & $\begin{array}{l}\text { Ya ini untuk kue, ibu saya membuat banten untuk dibawa ke Pura. } \\
\text { (Yes, this banana is for a cake, my mother makes offerings to be brought to the temple.) }\end{array}$ \\
\hline \multirow[t]{2}{*}{ (14) } & Gede: & $\begin{array}{l}\text { Kaтu mau ikut mancing hari Minggu? } \\
\text { (Do you want to go fishing on Sunday?) }\end{array}$ \\
\hline & Budi: & $\begin{array}{l}\text { Iya saya sudah cari telur angkrang. } \\
\text { (Yeah, I've been looking for an egg ant.) }\end{array}$ \\
\hline \multirow[t]{3}{*}{ (15) } & Gede: & $\begin{array}{l}\text { Nanti sore kamu tidak ngangon sapi? } \\
\text { (This afternoon, do not you shepherd a cow?) }\end{array}$ \\
\hline & Budi: & $\begin{array}{l}\text { Iya tapi di Loea. Soalnya Bapak yang suruh. } \\
\text { (Yes but in Loea. Since my father ask me) }\end{array}$ \\
\hline & Budi: & $\begin{array}{l}\text { Wah berarti sudah ada talinya. } \\
\text { (Well that means there is already a string) }\end{array}$ \\
\hline \multirow[t]{2}{*}{ (16) } & Budi: & $\begin{array}{l}\text { Kok kemarin kamu tidak main bola? } \\
\text { (Why did not you play the ball yesterday?) }\end{array}$ \\
\hline & Gede: & $\begin{array}{l}\text { Iya, kemarin saya pergi nyukutin padi di sawah. } \\
\text { (Yes, yesterday I went cleansing the grass rice in the fields) }\end{array}$ \\
\hline \multirow[t]{2}{*}{ (17) } & Gede: & $\begin{array}{l}\text { Cepat ke sini Gus, tancapkan saja kayu-nya di pundukan! } \\
\text { (Come here fast Gus, just plug the wood on the embankment!) }\end{array}$ \\
\hline & Agus: & $\begin{array}{l}\text { Aduh! Umpannya habis. } \\
\text { (Ouch! The feed is depleted) }\end{array}$ \\
\hline \multirow[t]{2}{*}{ (18) } & Wawan & $\begin{array}{l}\text { Putu katanya dihukum Pak Guru? } \\
\text { (Putu has been punished by the teacher?) }\end{array}$ \\
\hline & Gede: & $\begin{array}{l}\text { Benar, kemarin Putu dihukum pak guru karena ketahuan nonton tajen. } \\
\text { (Yes, yesterday Putu has been punished by the teacher because he was caught watching the cockfight) }\end{array}$ \\
\hline \multirow[t]{2}{*}{ (19) } & Wawan & $\begin{array}{l}\text { Wah kasihan dia pasti dimarahi ibunya. } \\
\text { (Well, so pity, he must be scolded by his mother) }\end{array}$ \\
\hline & Gede: & $\begin{array}{l}\text { Made juga dihukum. Ketahuan sedang main kocok. } \\
\text { (Made has also been punished. Because he was caught playing dice) }\end{array}$ \\
\hline
\end{tabular}


sciously avoids the use of the word 'ketua adat' (customary chairman) because in Gede's mind the concepts of 'bendesa' and 'ketua adat' are different.

\section{Overuse}

Overuse of certain grammatical forms in L2 acquisition can appear as a result of processes in intermediate languages, e.g., over-generalizing, as in the following conversations.

In sentence (24), in Balinese, the word 'be' means fish. However, in its use, the word 'be' represents two nouns; fish and meat. L2 Indonesian language learners, who are L1 Balinese, will translate ' $b e$ ' as a fish and generalize its use, so that it will appear 'ikan ayam'. In sentences (25), the use of word 'kurus' is to describe the coconut tree, because in Bali there are two words those are 'mokoh' which represent two meanings that are fertile or 'gemuk'(fat), and the word 'berag' which means infertile or 'kurus' (underweight). Both words are also used in plants such as"Punyan biune ento mokoh message" (The banana tree is very fertile) or "Punyan biune ento berag" (The banana tree is not fertile). In addition, language learners translated the word 'mokoh' and 'berag' as 'gemuk' and 'kurus' and generalize its use as can be seen in sentence (25).

In sentences (26), the use of word 'jarit' is analogous to the following words, Gauk = garuk (scratch), buuk =buruk (bad), and jaum = jarum (needle), and so on. Therefore, they think that 'jait' can be 'jarit' (sure). In sentence (27), the use of word 'makan es' (eat ice) is because in Balinese language, there is the word 'ngajeng' which means 'makan' (eat) and can be used in general 'makan dan minum' (food and drink). For example, 'Dek, ajeng jajane ento' (Dek, eat the cake), or it could be 'Dekengan susune ento' (eat the milk), or 'Dek ajeng ese ento' (Dek, eat the ice).

In Balinese, the use of word 'in $₫ \mathrm{~m}$ ' (drinking) is sometimes used only when drinking water. This form is subse-

\begin{tabular}{|c|c|c|}
\hline \multirow[t]{2}{*}{ (20) } & Bu Nyoman: & $\begin{array}{l}\text { Ini makan De. saya bungkus banyak. } \\
\text { (Please eat, bro. I pack a lot) }\end{array}$ \\
\hline & Gede: & $\begin{array}{l}\text { Tidak, perut saya wareg. } \\
\text { (No, I am full) }\end{array}$ \\
\hline \multirow[t]{2}{*}{ (21) } & Putu: & $\begin{array}{l}\text { Kamu tadi malam kok gak tidur-tidur? } \\
\text { (Why you did notsleep you last night?) }\end{array}$ \\
\hline & Gede: & $\begin{array}{l}\text { Iya, Putu ng } \llbracket \text { rok terus kalau tidur. } \\
\text { (Yes, Putu is snoring while he is sleeping) }\end{array}$ \\
\hline \multirow[t]{4}{*}{ (22) } & Gede: & $\begin{array}{l}\text { Bu, saya disuruh minta daun kayumanis. } \\
\text { (Madam, I was told to ask for a leaf of cinnamon) }\end{array}$ \\
\hline & Bu Warto: & $\begin{array}{l}\text { Tidak punya De. kalau kayu manisnya ada. } \\
\text { (I do not have, sister. I only have the cinnamon) }\end{array}$ \\
\hline & Gede: & $\begin{array}{l}\text { Itu di belakang banyak. Masak gak punya? Ini lho Bu } \\
\text { (There are alot behind. Why you say not. This is one) }\end{array}$ \\
\hline & Bu Warto: & $\begin{array}{l}\text { Lha itu bukan kayu manis. Itu pohon katuk De. } \\
\text { (Oh, that is not a cinnamon. That is a katuk tree) }\end{array}$ \\
\hline \multirow[t]{2}{*}{ (23) } & Wawan: & $\begin{array}{l}\text { Kamu tahu bapaknya si Komang? Dia dukun ya? } \\
\text { (Do you know Komang's father? He is the shaman) }\end{array}$ \\
\hline & Gede: & $\begin{array}{l}\text { Bukan, bapaknya bendesa, mengatur orang banyak. } \\
\text { (No, his father is a bandesa. He is the leader of our community) }\end{array}$ \\
\hline \multirow[t]{2}{*}{ (24) } & Nyoman: & $\begin{array}{l}\text { Sетиа ya? } \\
\text { (All these foods?) }\end{array}$ \\
\hline & Gede: & $\begin{array}{l}\text { Jangan, kamu ikan gabusnya saja, ikan ayam itu untuk adik. } \\
\text { (No, you eat the cork, the chicken is for your sister) }\end{array}$ \\
\hline \multirow[t]{2}{*}{ (25) } & Gede: & $\begin{array}{l}\text { Kalau pohon kelapa yang kurus itu, saya bisa panjat. } \\
\text { (The skinny coconut tree, I can climb) }\end{array}$ \\
\hline & Wawan: & $\begin{array}{l}\text { Ha ha ha badanmu kurus! } \\
\text { (Ha ha ha your body is skinny!) }\end{array}$ \\
\hline \multirow[t]{2}{*}{ (26) } & Gede: & $\begin{array}{l}\text { Dek, mana karung rumput yang baru dijarit ibu? } \\
\text { (Girl, where the new grass sack is stitched by the mother?) }\end{array}$ \\
\hline & Kadek: & $\begin{array}{l}\text { Itu di bawah meja. } \\
\text { (It's under the table) }\end{array}$ \\
\hline \multirow[t]{2}{*}{ (27) } & Putu: & $\begin{array}{l}\text { Kalau punya uang banyak, saya mau beli es tilot yang banyak. } \\
\text { (If I have a lot of money, I want to buy a lot of tilot } \\
\text { ice (hand-made ice cream) }\end{array}$ \\
\hline & Gede: & $\begin{array}{l}\text { Nanti Galungan jalan-jalan dan bisa makan es yang enak. } \\
\text { (Later on Galungan day I will tour the city and can eat ice) }\end{array}$ \\
\hline
\end{tabular}


quently generalized into Indonesian language by the language learners, so as the word 'makan es'(eat ice).

\section{DISCUSSION}

Suarta et al. (2013) conducted a research about the Morphology Interference of Balinese Language with Indonesian Spoken Language of Peers in Sub District West Toili. They concluded that the interference of the Balinese language with Indonesian language had happened to peers in the Sub District of West Toili. The interference was in the form of Indonesian with Balinese affixes such as the reduplication of Balinese in Indonesian language utterance. The cause of the interference of Balinese to Indonesian language is a habit factor of speakers in using Balinese as their first language.

In Gede's case, he tended to make avoidance and overuse unconsciously. Gede tried to use language which generated from his mind spontaneously. He spoke by involving his feeling and intuition. Referring to Chaer and Agustina (2009), the acquisition process experienced by him is a process of internalization.

Furthermore, the first language interference basically was caused by the influence of Balinese cultural which has been attached with Gede. This is in line with Pandaraga (2015), he states that a second language speaker has his own strategy to avoid 'face threatening act'. He emphasizes that different culture has important contribution to the strategy of avoiding faced threat. In Gede's conversation, it could be noticed that the strategy applied by him was using diction out of his first language.

Avoidance by a child named Gede (data source) is caused by the differences in the cultural background of Balinese and Indonesian language that he learnt. This is particularly relevant to the objective of the contrastive analysis that is not only to compare language elements and linguistic systems between the first language LI and the second language L2, but also to describe the cultural background of the two languages. The results of this study can be used in teaching a second or foreign language. In addition, Lado (1964, as cited in Ellis, 1986) states that we can predict and describe the pattern that will cause the difficulty by systematically comparing the language and culture being learnt with the native language and the culture of learner.

Gede's Balinese cultural background leads him to be a polite child. Since he was a toddler, Gede always listens to a polite language. Thus, he preferred to use Balinese than to use Indonesia language in his daily conversation for example how the word 'plebon' (corpse burned) is used in conversation. Moreover, He does not use the word burned and his choice of the word 'plebon' is also the right one. In fact, in Balinese language, there is 'ngaben' which means 'burned' besides the word 'plebon'. Gede also turned out not to use the word 'ngaben' because in Hindu culture, the value of word 'ngaben' is lower than 'plebon'. For a highly respected person, He uses the best word choice as well as 'plebon'. It is the results of Gede's knowledge that he obtained from his family that the best word to be used in a context of burning the dead bodies was 'plebon'. Then, his diction is brought into Indonesian context. Even though, in this case Gede should have used the word burned.

In Balinese culture, there is a term 'sor singih'. This 'sor singgih' is used in certain language circles. Among the Balinese, the understanding of "sor singgih" is taught from a very young age (toddlers). Because there is a punishment for every inappropriate language useage, the 'sor singih' becomes a habitual action for the Balinese. For instance, the use of the word "Gusti Aji" in sentence (2) in which the speaker used the word 'Gusti Aji' and not 'Bapak' when he is calling his father. In this context, the speaker avoids the use of word 'Bapak' since his father is a noble and a married man.

In addition, contrastive analysis consists of two aspects, namely psychological and linguistic aspects. The psychological aspect is an aspect based on behaviorism theory while the linguistic aspect is based on structural linguistics. According to the theory of learning behaviorism, learning L2 is considered as an attempt to master the habits of L2 (new language habits) by memorizing the dialogue, imitating the speech of others, or tracing the use of language patterns and its acquisition. The new habits are meant to shift the old habits of L1 into new habits of L2 (Dawud, 2002; Tolla, 1990). This is similar to what is expressed by Bright and McGregor (1970, as cited in Ellis, 1986) that old habits enter the way of learning the new habits. The basic theory of the psychological aspect does not seem to be a problem, but the structural linguistic aspect needs to be discussed further. The rational is that the contrastive analysis, as described by Lado (1964, as cited in Ellis, 1986), is not only to compare languages and linguistic elements in first language and second language but also to illustrate the cultural background of both L1 and L2. Comparing the cultural background would not be appropriate if only analyzing its structure; instead, it should be analyzed from the functional lingusitic aspects. An example was shown in the case of Gede in which he avoided certain words in Indonesian and chooses a subtle and polite Javanese language that is more relevant to sociolinguistics and pragmatics feature. In this sense, Gede prioritizes the functional linguistic aspect.

In addition, first language grammatical tools processed in the brain can easily interfere with the acquisition of a second language. The notion of interference occupies a central place in the acquisition of a second language. This is similar to what is stated by Bright and McGregor (1970, as cited in Ellis, 1986), who argue that it is a truth if old habits enter into the way of learning new habits.

One of the phenomena, in this case, is the overuse of certain grammatical forms in the acquisition of L2. Overuse can be a result of several processes in intermediate language. An example is an over-generalizing that was found in the conversation (25). In Balinese language, there is no difference between the word fish and meat, both are called "be". Chicken = be siap, goat meat = be kambing (goat), Salmon = be salmon, Shark = be hiu (Shark). The word "be" 
is generalized into a second language, so it appears in the word "ikan ayam" (chicken fish) which it should be "chicken meat".

The facts of language acquisition in the form of overuse or more specifically the acquisition of language in over-generalization is in line with what was stated by Dawud (2002) and Tolla (1990) that in the acquisition of new habits L2, language learners transfers their old habits (L1). So, the teacher must continually correct the deviation of language learners in their second language acquisition process (L2), or possibly in learning a foreign language.

\section{CONCLUSION}

To conclude, the avoidance and overuse of Indonesian language among Balinese children is very diverse. As mentioned early in background of this study, the avoidance and overuse are types of negative language transfer phenomena faced by Balinese children. Then, it is a serious issue in the acquisition of Indonesian language as a second language. In this study, the researcher found that the most common condition that leads the speaker doing avoidance is the politeness reason. On the other hand, over using happens as a consequence of the over generalization towards the meaning of certain words. The researcher concluded that in order to minimize those two negative transfers of language in second language teaching and learning process, language teachers should facilitate their students' cultural background as well as involve their students' mother tongue as the language of instruction in classroom practice during their preliminary meeting or teaching.

One basic pedagogic implication of this research is that if teachers are aware of students' avoidance and overuse, they can design a contextual teaching method to be applied. This would decrease the possibility of making avoidance and overuse among students. Moreover, theoretically, this research contributes to the second language acquisition theory especially in case of students' cultural background intervention during their second language acquisition process. In this, students' second language performance could not only depend on their psycholinguistic mastery but also on their cultural background.

Hopefully, the findings of this research can be a reference for second language practitioners in their teaching practices. It can be useful for Indonesian language teachers to make them aware of the language transfer phenomena. This awareness could help them to design very efficient and effective learning activities inside the classroom.

Since this research is only gathering data from a single data source namely Gede, it is recommended for further research to be conducted using many samples. In terms of data source's cultural background, investigating various cultural backgrounds would be more worth to be discussed and valid to be employed.

Finally, Indonesian language teachers should realize that both language transfer and overuse phenomena can be used to design very efficient and effective language learning materials for classroom teaching. They can be sources or reference in designing the lesson plan, decision making, and selecting an appropriate method for language instruction, and so on. Consequently, this could result in improvement in the process of students' second language acquisition.

\section{REFERENCES}

Benešová, E. (2013). Treatment of Error in Developing Speaking Skills. Retrieved on June 21, 2017 from: https://goo.gl/mKJCF6

Brahim, T. K. (1995). Second Language Acquisition. Jakarta: Depdikbud

Bright, J. \& McGregor, G. (1970).Teaching English as a Second Language: Theory and Techniques for the Secondary Stage. London: Longman.

Brooks, N. (1960). Language and Language Learning. Harcourt, Brace \& World, Inc.; ALM edition.

Brown, D. (1980). Principles of Learning a Second Language. Pearson Education

Chaer, A. \& Agustina, L. (2009). Psikolinguistik: Kajian teoretik. Jakarta: Rineka Cipta.

Clark, E. V. (2003). First language acquisition. Cambridge: Cambridge University Press.

Dawud (2002). Perkembangan dan keterhubungan filsafat, psikologi, linguistik danpembelajaran bahasa. Materi Prapas-casarjana Program Studi Pendidikan Bahasa Indonesia tahun 2002. Universitas Negeri Malang (June 18, 2017).

Dulay, H., \& Burt, M. (1977). Remarks on Creativity in Language Acquisition. In M. Burt, H. Dulay \& M. Finnochiaro (Eds.), Viewpoints on English as a Second Language (pp. 95-126). New York: Regents Ellis, R. (1986). The study of second language acquisition. New York: Oxford University Press.

Ellis, R. (1986). Understanding Second Language Acquisition. Oxford: Oxford University Press.

Dewantara, I.P.M. Analisis bandingan bahasa bali - bahasa indonesia. [Online] Available: https://www.academia. edu/5714570/Analisis_Bandingan_Bahasa_Bali-Bahasa_Indonesia_Oleh_I_Putu_Mas_Dewantara(January 28, 2016)

James, C. (1980). Contrastive Analysis. Harlow Essex: Longman Group Ltd.

Krashen, S. (1983). Second language acquisition and second language learning. Oxford: Pergamon Press.

Lightbown, P. M. \& Spada, N. (2013). How languages are learned? (4 $4^{\text {th }}$ Edition). Oxford: OUP.

Naska, I. (2017). Analisis Kontrastif Dan Analisis Kesalahan Dalam Pembelajaran Bahasa Arab. Fakultas Agama Islam Universitas Muhammadiyah Sumatera Barat, Indonesia. [Online] Available: https://www.academia. edu/8817441/ANALISIS KONTRASTIF DAN ANALISIS_KESALAHAN_DALAM_PEMBELAJARAN_BAHASA_ARAB (July 8, 2017)

Rahayu, A. C. (2012). Teori Transfer dan Teori Interferensi dalam Pemerolehan Bahasa Kedua Atau Bahasa Target. [Online] Available http://jurnal.untag-sby.ac.id/index. php/parafrasa/article/view/210/181. (June 18, 2017) 
Schutz, R. (2017). Stephen Krashen's Theory of Second Language Acquisition (Last Version). [Online] Available http://www.sk.com.br/sk-krash.html. (July 16, 2017)

Suarta, D.G.A, Baruadi, M.K., \& Umar F. AR. (tt). Interferensi morfologi bahasa bali terhadap bahasa indonesia lisan oleh teman sebaya di kecamatan toili barat. [Online] Available http://kim.ung.ac.id/index. php/KIMFSB/article/viewFile/3218/3194. (January 28,2016).
Susanto. H. (2016). Analisis Kontrastif. Online] Available https://bagawanabiyasa.wordpress.com/2016/08/14/ analisis-kontrastif/. (June 18, 2017)

Tolla, A. (1990). Tiga Pandangan dalam Pemerolehan Bahasa: Skinner, Chomsky, dan Krashen. Dalam Nurhadi dan Roekhan (Eds), Dimensi-dimensi dalam belajar bahasa kedua (hlm.11-13). Bandung: Sinar Baru.

Yunita, L. S. (2012). Transfer Negatif Pemerolehan Bahasa Indonesia Anak Usia 8 Tahun Yang Berbahasa Ibu Bahasa Jawa. Jurnal Inspirasi Pendidikan Universitas Kanjuruhan Malang. 